\title{
The intricate relationship amongst pain intensity, fear and avoidance
}

Citation for published version (APA):

Vlaeyen, J. W. S. (2016). The intricate relationship amongst pain intensity, fear and avoidance.

Scandinavian Journal of Pain, 13, 128-129. https://doi.org/10.1016/j.sjpain.2016.08.010

Document status and date:

Published: 01/10/2016

DOI:

10.1016/j.sjpain.2016.08.010

Document Version:

Publisher's PDF, also known as Version of record

\section{Please check the document version of this publication:}

- A submitted manuscript is the version of the article upon submission and before peer-review. There can be important differences between the submitted version and the official published version of record.

People interested in the research are advised to contact the author for the final version of the publication, or visit the DOI to the publisher's website.

- The final author version and the galley proof are versions of the publication after peer review.

- The final published version features the final layout of the paper including the volume, issue and page numbers.

Link to publication

\footnotetext{
General rights rights.

- You may freely distribute the URL identifying the publication in the public portal. please follow below link for the End User Agreement:

www.umlib.nl/taverne-license

Take down policy

If you believe that this document breaches copyright please contact us at:

repository@maastrichtuniversity.nl

providing details and we will investigate your claim.
}

Copyright and moral rights for the publications made accessible in the public portal are retained by the authors and/or other copyright owners and it is a condition of accessing publications that users recognise and abide by the legal requirements associated with these

- Users may download and print one copy of any publication from the public portal for the purpose of private study or research.

- You may not further distribute the material or use it for any profit-making activity or commercial gain

If the publication is distributed under the terms of Article $25 \mathrm{fa}$ of the Dutch Copyright Act, indicated by the "Taverne" license above, 


\title{
The intricate relationship amongst pain intensity, fear and avoidance
}

\author{
Johan W.S. Vlaeyen ${ }^{\mathrm{a}, \mathrm{b}, *}$ \\ a Research Group Health Psychology, Faculty of Psychology and Educational Sciences, KU Leuven, University of Leuven, Belgium \\ ${ }^{\mathrm{b}}$ Department of Clinical Psychological Science, Maastricht University, The Netherlands
}

\section{Fear of an internal threat like pain causes avoidance of pain-provoking movements}

Fear is an emotional response that occurs when the individual is directly threatened with a potentially life-threatening event, and the behavioural manifestation of fear usually is immediate escape from that event. Fear has been studied extensively in situations where there is an external threat, such as violence by another person or an animal. The automatic response is to attack or to escape the dangerous object and its location as fast as possible. The situation is somewhat different when the threat is coming from within the body, such as musculoskeletal, neuropathic or visceral pain, and from which escape is not possible. In the absence of an escape route, the only possibility is to prevent or avoid an increase of that pain sensation by staying immobilized or moving slowly and carefully. Such acute painful events are salient learning experiences. In most cases, the pain will diminish after a while, and the person might remember that just staying still or moving slowly is associated with less pain. As a result, this behavioural avoidance pattern is likely to be repeated in subsequent recurrences of pain or early signs of such a pain episode.

\section{Avoidance of pain-provoking movements facilitates healing, but if continued after a healed injury may create abnormal and prolonged fear of pain and movement}

There is a general agreement that the avoidance response is adaptive, and that it may facilitate the healing process. This line of thought is of course correct under the assumption that pain is a reflection of some lesion in the body. However, how do we know that a to-be-healed event has taken place in the first place, and similarly, how do we know when healing has occurred, and when the protective behaviours are not necessary anymore? Most individuals will use the pain experience as the most important source of information to infer some kind of physical anomaly, and the question is whether this inferential process is always accurate. Moreover, avoidance is a behavioural action that may interfere with

DOI of refers to article: http://dx.doi.org/10.1016/j.sjpain.2016.06.011.

* Correspondence to: Research Group Health Psychology, KU Leuven, University of Leuven, Tiensestraat 102, box 3726, 3000 Leuven, Belgium. Fax: +32 016325923.

E-mail address: johannes.vlaeyen@kuleuven.be or prevent other behaviours that facilitate daily life personal goal pursuit [1]. The more avoidance behaviours, the more likely that the person feels disabled. In other words, fear of pain or pain-related stimuli (such as movements) will be associated with protective avoidance behaviours that initially maybe facilitate healing, but in the long run maintains disability. Also, avoidance behaviours may become habits that persist, also when fear has diminished. This is in fact the quintessence of the fear-avoidance model, introduced by Lethem et al., more than 30 years ago [2,3], and later refined by others [4-6].

\section{Treat pain-related fear in order to decrease risk of chronic disability}

Since the introduction of the fear-avoidance model, numerous studies have examined the effects of pain-related fear on cognitive [7], brain [8] and motor function [9] in various pain patient groups. In order to summarize these findings, a recent meta-analysis convincingly showed that the relation between pain-related fear and disability is moderate to large in magnitude, and quite stable across demographic and pain characteristics [10]. The conclusion of that study was that pain-related fear might be an important target for treatments aimed at reducing pain-related disability.

\section{Fear-avoidance may inflate the patient's report of pain}

However, there are reasons to believe that fear and avoidance behaviour also influence the report of pain. Several prospective studies revealed that fear of pain is a strong predictor of pain outcomes later on [11], although another study demonstrated that pain-related fear was found to be a consequence rather than an antecedent of pain severity [12]. These findings suggest a unique but intricate relationship between pain severity and pain-related fear, which is corroborated in several other studies as well [13].

\section{Association between fear-avoidance and reported pain intensities}

These and other findings must have inspired Emily Kroska who performed a meta-analysis with the aim to study the association between pain-related fear and pain intensity reports, published in this issue of the Scandinavian Journal of Pain [14]. The author performed an impressive amount of work, selecting 799 studies 
for consideration using keywords, and finally coding 118 studies for the current meta-analysis. She then calculated effect sizes, reflecting the strength of the associations found, using the correlation coefficients of the pain and fear-avoidance variables. Given that they are standardized (using Fisher's Z transformations), these effect sizes have the advantage of direct comparison in different studies that utilized different variables and different scales of measurement of the same variable. The results are interesting, as the standardized correlations between the pain-related fear and pain intensity measures vary between 0.18 and 0.28 , suggesting smallto-moderate positive association amongst these variables.

\section{Motivational factors may influence fear-of-pain and avoidance}

The reason why not stronger associations were found is not totally clear, but one possibility is that the presence of pain may not always be a reason to rise fear and to avoid activities. Fear is more likely to occur when the meaning attached to pain is negative, and when it threatens the sense of self [15]. In most of the studies that were included in Kroska's meta-analysis [14], the motivational dimension of pain was not addressed, and this is a novel and emerging field in pain psychology [16]. Vice versa, reports of fearful beliefs and avoidance can persist as habits, also when pain has diminished. Interestingly, fear-avoidance beliefs have also been observed in healthy individuals [17].

\section{Moderation analyses - cultural influences on fear-avoidance}

Another interesting feature of Kroska's study is the inclusion of moderation analyses, providing additional depth into the relationship between fear-avoidance and pain intensity [14]. Moderation analyses are usually conducted when the relationship between the variables of interest are rather weak to moderate, which is indeed the case here. In fact, moderation analyses consist of a statistical way to empirically derive subgroups of subjects who share features. This is one of the first meta-analyses in the pain field including "culture" as a moderator, using Hofstede's dimensions of national culture (see $[14,18]$ ). The results indicated that the association between fear-avoidance and pain intensity was stronger in cultures where individuals accept an unequal distribution of power in society, in cultures that value collectivist ideals, and in cultures where restraint is more important than short-term gratification [14]. Although this is an interesting and seldom researched topic, an unanswered question is what the moderation by culture actually means in the context of fear-avoidance and pain. The author did not formulate clear hypotheses, which is something that merits more thought. Also, and acknowledged by the author, even though Hofstede's model is generally accepted, its validity has also been criticized, e.g. by McSweeney [18]. Some more work is necessary here.

\section{Implications of the Kroska study results [14] on behavioural treatments of chronic pain}

What are the implications of this meta-analytic review for behavioural treatments in chronic pain populations? Cognitivebehavioural therapy, and exposure-based treatments in particular, have shown to be successful in improving psychological and physical functioning among chronic pain patients [19]. The primary aim of these treatments is not the reduction of pain, but the restoration of daily functioning and the achievement of personal goal. Nevertheless, several studies clearly demonstrate that a successful exposure treatment can be associated with the reduction of selfreported pain severity, albeit with some delay $[20,21]$. For example, den Hollander et al. [21], compared the effectiveness of exposure and treatment as usual in patients with complex regional pain syndrome (CRPS-I), and clearly demonstrated that the exposure treatment was superior not only in reducing pain-related fear, but also in reducing self-reported pain intensity. Typical for the exposure treatment provided to these patients is not just approaching activities in general, but approaching activities that are customized and geared towards individuals goals and personally valued activities. It is likely that experiencing the - by the patients almost forgotten-possibility to actually do what they value most in life, brought back meaningfulness. These results are reminiscent of one of the pioneering behaviourists Wilbert Fordyce's sayings: "Pain patients would suffer less if they have something better to do" [22].

\section{Concluding remark}

In sum, Kroska's work [14] is an important step in the understanding of the role of pain-related fear in the expression of pain in individuals with chronic pain, and it encourages us to scrutinize further some of the surprising and unexplained findings connected with the fear-avoidance model of pain [6].

\section{References}

[1] Crombez G, Lauwerier E, Goubert L, Van Damme S. Goal pursuit in individuals with chronic pain: a personal project analysis. Front Psychol 2016;7:966.

[2] Lethem J, Slade PD, Troup JD, Bentley G. Outline of a fear-avoidance model of exaggerated pain perception-I. Behav Res Ther 1983;21:401-8.

[3] Philips HC. Avoidance behaviour and its role in sustaining chronic pain. Behav Res Ther 1987;25:273-9.

[4] Asmundson GJ, Norton PJ, Norton GR. Beyond pain: the role of fear and avoidance in chronicity. Clin Psychol Rev 1999;19:97-119.

[5] Simons LE, Kaczynski KJ. The Fear Avoidance model of chronic pain: examination for pediatric application. J Pain 2012;13:827-35.

[6] Vlaeyen JW, Crombez G, Linton SJ. The fear-avoidance model of pain. Pain 2016;157:1588-9.

[7] Gatzounis R, Schrooten MG, Crombez G, Vlaeyen JW. Interrupted by pain: an anatomy of pain-contingent activity interruptions. Pain 2014;155:1192-5

[8] Meier ML, Stampfli P, Vrana A, Humphreys BK, Seifritz E, Hotz-Boendermaker $S$. Neural correlates of fear of movement in patients with chronic low back pain vs. pain-free individuals. Front Hum Neurosci 2016;10:386.

[9] Thomas JS, France CR. Pain-related fear is associated with avoidance of spinal motion during recovery from low back pain. Spine (Phila Pa 1976) 2007;32:E460-6.

[10] Zale EL, Lange KL, Fields SA, Ditre JW. The relation between pain-related fear and disability: a meta-analysis. J Pain 2013;14:1019-30.

[11] Archer KR, Seebach CL, Mathis SL, Riley 3rd LH, Wegener ST. Early postoperative fear of movement predicts pain, disability, and physical health six months after spinal surgery for degenerative conditions. Spine J 2014;14:759-67.

[12] Gheldof EL, Crombez G, Van den Bussche E, VinckJ, Van Nieuwenhuyse A, Moens G, Mairiaux P, Vlaeyen JW. Pain-related fear predicts disability, but not pain severity: a path analytic approach of the fear-avoidance model. Euro J Pain 2010;14:e871-9.

[13] Labrenz F, Icenhour A, Schlamann M, Forsting M, Bingel U, Elsenbruch S. From Pavlov to pain: how predictability affects the anticipation and processing of visceral pain in a fear conditioning paradigm. Neuroimage 2016;130:104-14.

[14] Kroska EB. A meta-analysis of fear-avoidance and pain intensity: the paradox of chronic pain. Scand J Pain 2016;13:43-58.

[15] Morley S, Davies C, Barton S. Possible selves in chronic pain: self-pain enmeshment, adjustment and acceptance. Pain 2005;115:84-94.

[16] Crombez G, Eccleston C, Van Damme S, Vlaeyen JW, Karoly P. Fear-avoidance model of chronic pain: the next generation. Clin J Pain 2012;28:475-83.

[17] Houben R, Leeuw M, Vlaeyen J, Goubert L, Picavet H. Fear of movement/injury in the general population: factor structure and psychometric properties of an adapted version of the Tampa Scale for Kinesiophobia. J Behav Med 2005;28:415-24.

[18] McSweeney B. Hofstede's model of national cultural differences and their consequences: a triumph of faith - a failure of analysis. Hum Relat 2002;55:89-117.

[19] Vlaeyen JW, Morley S, Linton S, Boersma K, De Jong J. Pain-related fear: exposure-based treatment for chronic pain. Seattle: IASP Press; 2012.

[20] de Jong JR, Vlaeyen JW, van Eijsden M, Loo C, Onghena P. Reduction of painrelated fear and increased function and participation in work-related upper extremity pain (WRUEP): effects of exposure in vivo. Pain 2012;153:2109-18.

[21] den Hollander M, Goossens M, de Jong J, Ruijgrok J, Oosterhof J, Onghena P, Smeets R, Vlaeyen JW. Expose or protect? A randomized controlled trial of exposure in vivo vs. pain-contingent treatment as usual in patients with complex regional pain syndrome type 1 . Pain 2016 [Epub ahead of print].

[22] Fordyce WE. Pain and suffering. A reappraisal. Am Psychol 1988;43:276-83. 